\title{
Kepemilikan Manajerial, Kebijakan Pembayaran Dividen dan Efek Moderasi Penurunan Tarif PPh Dividen WPOP Dalam Negeri
}

\author{
Ninik Zulaikah \\ Alumni Universitas Airlangga, Jl. Darmawangsa Dalam Selatan, Surabaya 60286 \\ Email: ninik_zulaikah@yahoo.com \\ Mienati Somya Lasmana \\ Universitas Airlangga, Jl. Darmawangsa Dalam Selatan, Surabaya 60286
}

\begin{abstract}
ABSTRAK
Penelitian ini bertujuan untuk menguji pengaruh moderasi penurunan tarif pajak penghasilan dividen wajib pajak orang pribadi dalam negeri terhadap kepemilikan manajerial dan kebijakan pembayaran dividen pada perusahaan yang terdaftar di Bursa Efek Indonesia. Perusahaan yang diteliti sebanyak 88 perusahaan terdiri dari perusahaan yang melakukan membayarkan dividen minimal setahun sekali secara berturut-turut mulai tahun 2007 hingga tahun 2009, dan ada kepemilikan saham oleh pihak manajemen. Hasil penelitian menunjukkan kepemilikan manajerial berpengaruh positif dan signifikan terhadap kebijakan pembayaran dividen perusahaan, dan penurunan tarif pajak penghasilan dividen wajib pajak orang pribadi dalam negeri memoderasi pengaruh kepemilikan manajerial terhadap peningkatan kebijakan pembayaran dividen perusahaan.
\end{abstract}

Kata Kunci: Tarif pajak, dividen, wajib pajak, kepemilikan manajerial.

\begin{abstract}
This study aims to examine the moderating effect of reduction of dividend income tax rate for domestic individual taxpayers toward managerial ownership and dividend payout policies on companies listed in Indonesia Stock Exchange. The company surveyed a total of 88 companies are companies that pay dividends at least once a year consecutively from 2007 until 2009, and no stock ownership by management. The results show a positive and significant effect of managerial ownership to the company's dividend policy and dividend income tax rate for domestic personal taxpayers moderate the effect of managerial ownership on the increase in dividend payout policy.
\end{abstract}

Keywords: Tax rate, devidens, taxpayers, managerial ownership.

\section{PENDAHULUAN}

Terhitung sejak tanggal 1 Januari 2009, besarnya tarif pajak penghasilan $(\mathrm{PPh})$ dividen Wajib Pajak Orang Pribadi (WPOP) dalam negeri diturunkan dari semula sebesar $15 \%$ bersifat tidak final menjadi sebesar $10 \%$ bersifat final. Perubahan tersebut diatur dalam Undang-Undang Nomor 7 Tahun 1983 sebagaimana telah diubah terakhir dengan Undang-Undang Nomor 36 Tahun 2008 tentang Pajak Penghasilan (UU PPh No. 36 Tahun 2008). Pada pasal 17 ayat $2 \mathrm{c}$ menyebutkan, tarif yang dikenakan atas penghasilan berupa dividen yang dibagikan kepada wajib pajak orang pribadi (WPOP) dalam negeri adalah paling tinggi sebesar $10 \%$ (sepuluh persen) dan bersifat final. Ketentuan lebih lanjut mengenai besarnya tarif diatur dalam Peraturan Pemerintah No. 19 Tahun 2009 yang mana pada pasal 1 disebutkan bahwa, penghasilan berupa dividen yang diterima atau diperoleh WPOP dalam negeri dikenakan $\mathrm{PPh}$ sebesar 10\% dan bersifat final.

Ada dua hal penting terkait dengan keluarnya Peraturan Pemerintah No. 19 Tahun 2009 yaitu pertama tarif $\mathrm{PPh}$ dividen WPOP dalam negeri turun dari $15 \%$ menjadi $10 \%$. Kedua sifat 
pengenaannya dari tidak final menjadi final. Bersifat tidak final artinya atas penghasilan dividen yang diterima atau diperoleh WPOP akan digabungkan dengan penghasilan lain pada SPT Tahunan dan dikenakan tarif progresif sampai dengan $35 \%$. Bersifat final artinya atas penghasilan dividen tidak perlu digabungkan dengan penghasilan lain. WPOP sebagai pemegang saham atas penghasilan dividen hanya dikenakan tarif sebesar $10 \%$ dengan withholding system.

Sedangkan tujuan dari penurunan tarif $\mathrm{PPh}$ dividen WPOP dalam negeri yang terdapat dalam pokok-pokok perubahaan UU PPh No. 36 Tahun 2008, ada tiga alasan yaitu: pertama, UU PPh tetap menganut classical system sehingga dividen tetap merupakan objek pajak; kedua, diberikan insentif berupa tarif $\mathrm{PPh}$ yang rendah atas dividen dengan tujuan: a) agar beban pajak yang ditanggung pemegang saham orang pribadi (OP) dapat dikurangi; b) mendorong perusahaan agar mendistribusikan penghasilannya kepada pemegang saham daripada laba ditahan; c) karena investasi dalam bentuk penyertaan modal mengandung risiko yang lebih besar daripada investasi dalam bentuk deposito dan obligasi; ketiga tarif final memberikan kesederhanaan administrasi bagi WP dan Direktorat Jenderal Pajak (DJP).

Berdasarkan data dari Bursa Efek Indonesia (BEI), dalam IDX Statistics, jumlah perusahaan yang membagi dividen selama periode tahun 20062010, mengalami perubahaan yang fluktuatif. Sedangkan periode tahun 2008-2010 jumlah perusahaan yang membagi dividen terus mengalami peningkatan jika dibandingkan dengan tahun sebelumnya, data jumlah perusahaan yang terdaftar mulai tahun 2006 (344 perusahaan), tahun 2007 (383 perusahaan), tahun 2008 (396 perusahaan), tahun 2009 (398 perusahaan) dan tahun 2010 (420 perusahaan). Yang membagi dividen mulai tahun 2006 (158 perusahaan), tahun 2007 (153 perusahaan), tahun 2008 (157 perusahaan), tahun 2009 (168 perusahaan) dan tahun 2010 (194 perusahaan). Jika dibandingkan antara jumlah perusahaan yang terdaftar dan yang membagi dividen mulai tahun 2006 (45,93\%), tahun 2007 $(39,95 \%)$, tahun $2008(42,21 \%)$, tahun 2009 $(46,19 \%)$ dan tahun $2010(46,19 \%)$. Dari data tersebut pada periode 2009 dan 2010 terdapat peningkatan pembayaran dividen. bersamaan dengan perubahan peraturan atas tarif $\mathrm{PPh}$ WPOP dalam negeri mulai 01 Januari 2009.

Peristiwa serupa terjadi di Amerika pada bulan Mei 2003, dengan disyahkannya The Jobs and Growth Tax Relief Reconciliation Act of 2003, mengatur tarif $\mathrm{PPh}$ dividen orang pribadi turun dari $38,6 \%$ menjadi $15 \%$. Hal ini direspon positif oleh sejumlah perusahaan dengan meningkatkan pembayaran dividen. Dalam Nam et al. (2004) dari data Standard \& Poor's, menyatakan bahwa ada sebanyak 1.101 perusahaan telah meningkatkan pembayaran dividen atau membayar dividen untuk pertama kalinya. Jumlah ini secara signifikan lebih besar dari periode tahun sebelumnya. Peningkatan pembayaran dividen dimulai kuartal ketiga (Q3) 2003 dan kuartal keempat (Q4) 2003.

Beberapa penelitian yang merespon penurunan tarif PPh dividen orang pribadi tahun 2003 di Amerika diantaranya, Brown et al. (2004), Blouin et al. (2004), Chetty dan Saez (2004) serta Nam et al. (2004) yang menemukan bahwa penurunan tarif $\mathrm{PPh}$ dividen orang pribadi memengaruhi pembayaran dividen. Dengan menginteraksikan kepemilikan manajerial dengan tarif $\mathrm{PPh}$ dividen orang pribadi ditemukan bahwa kepemilikan manajerial (managerial ownership) atau pihak manajemen (insider) mempunyai pengaruh yang positif dan signifikan terhadap peningkatan kebijakan pembayaran dividen. Yang artinya pihak yang terlibat dalam pengambilan keputusan dan memiliki saham dalam perusahaan, akan mendorong kebijakan pembayaran dividen ketika ada penurunan tarif $\mathrm{PPh}$ dividen WPOP.

Nam et al. (2004) dan Chetty dan Saez (2004) menemukan adanya principal-agent problem dalam menentukan respon penurunan tarif pajak penghasilan dividen orang pribadi dengan meningkatkan pembayaran dividen. Ketika tarif pajak penghasilan dividen orang pribadi turun maka para manajer yang memilik saham besar memanfaatkan dividen untuk mendistribusikan laba perusahaan, untuk meningkatkan kekayaan pribadi dari penghasilan dividen dan mendapatkan keuntungan dari penghematan beban pajak yang harus ditanggung. Para manajer pemegang saham sebagai principal dan agent yang bertindak untuk kepentingan keuntungan sendiri dengan membagi dividen akan berbeda dengan kepentingan pemegang saham lain yang menghendaki inventasi. Jensen dan Meckling (1976) mengemukakan teori keagenan bahwa kepentingan manajemen dan kepentingan pemegang saham seringkali bertentangan, sehingga bisa menyebabkan terjadinya konflik diantara keduanya.

Penelitian ini bertujuan untuk menguji pengaruh moderasi penurunan tarif $\mathrm{PPh}$ dividen WPOP dalam negeri terhadap hubungan antara kepemilikan manajerial dan kebijakan pembayaran dividen. Masalah dalam penelitian ini adalah: (1) Apakah kepemilikan manajerial berpengaruh signifikan terhadap kebijakan pembayaran dividen perusahaan? (2) Apakah penurunan tarif pajak penghasilan dividen wajib pajak orang pribadi dalam negeri memoderasi pengaruh ke- 
pemilikan manajerial terhadap kebijakan pembayaran dividen perusahaan?

Bagian berikut dari tulisan ini membahas secara berturut-turut mengenai pengembangan teori dan hipotesis, metode penelitian, dan teknik analisis data. Kemudian dilanjutkan dengan pengujian hipotesis dan pembahasan, dan ditutup dengan kesimpulan dan saran-saran untuk penelitian dimasa yang akan datang.

Pasal 17 ayat 2c UU PPh No. 36 Tahun 2008 berbunyi tarif yang dikenakan atas penghasilan berupa dividen yang dibagikan kepada WPOP dalam negeri adalah paling tinggi sebesar $10 \%$ (sepuluh persen) dan bersifat final. Ketentuan lebih lanjut mengenai besarnya tarif $\mathrm{PPh}$ dividen WPOP dalam negeri diatur dalam Peraturan Pemerintah No. 19 Tahun 2009, Pasal 1 berbunyi penghasilan berupa dividen yang diterima atau diperoleh WPOP dalam negeri dikenakan $\mathrm{PPh}$ sebesar $10 \%$ dan bersifat final.

Perubahaan dan penurunan tarif $\mathrm{PPh}$ dividen WPOP dalam negeri akan memberikan penghematan $\mathrm{PPh}$ sampai dengan $25 \%$ dari peraturan sebelumnya selain itu juga meningkatkan kekayaan pribadi. Sesuai dengan pernyataan Nam et al. (2004) dan Chetty dan Saez (2004) ketika tarif $\mathrm{PPh}$ dividen WPOP turun maka para manajer yang memiliki saham besar memiliki kesempatan untuk meningkatkan kekayaan pribadi dari penghasilan dividen dan mendapatkan keuntungan dari penghematan beban pajak yang harus ditanggung. Hal ini disebabkan manajerial adalah pihak yang paling tahu tentang kondisi perusahaan, sehingga akan mampu mendorong perusahaan untuk membagikan dividen. UndangUndang Perseroan Terbatas No.40 Tahun 2007 Pasal 71 ayat 1 , keputusan pembagian dividen perusahaan ditetapkan melalui Rapat Umum Pemegang Saham (RUPS). Pasal 72 ayat 4 pembagian dividen interim ditetapkan berdasarkan keputusan Direksi setelah memperoleh persetujuan Dewan Komisaris.

Undang-Undang Nomor 7 Tahun 1983 sebagaimana telah diubah terakhir dengan UndangUndang Nomor 36 Tahun 2008 tentang Pajak Penghasilan, Pasal 4 ayat 1 huruf g, dalam penjelasan yang dimaksud pengertian dividen adalah: 1) pembagian laba baik secara langsung ataupun tidak langsung, dengan nama dan dalam bentuk apapun. Dividen adalah imbalan atau kompensasi yang diterima atau diperoleh atas investasi atau penyertaan modal pada suatu perusahaan atau badan usaha. Sebagai imbalan atas investasi atau penyertaan modal pada suatu perusahaan atau badan usaha, umumnya dividen hanya diberikan atau dibayarkan apabila perusahaan atau badan usaha terkait memperoleh keuntungan dari kegiatan usahanya (Harnanto, 2003 : 299).

Penurunan tarif $\mathrm{PPh}$ dividen WPOP dalam negeri menjadi sebagai variabel moderator untuk mengetahui pengaruh kepemilikan manajerial terhadap kebijakan pembayaran dividen. Variabel moderasi (moderating variable) adalah suatu variabel independen yang akan memperkuat atau memperlemah hubungan antara variabel independen terhadap variabel dependen. Rumus persamaan adalah $Y=a+\beta_{1} X_{1}+\beta_{3} X_{1} Z+e$, yaitu variabel perkalian antara $X_{1}$ dan $Z$ merupakan variabel moderating oleh karena menggambarkan pengaruh moderating variabel $Z$ terhadap hubungan $X_{1}$ dan $Y$ (Ghozali, 2009 :199). Interpretasi dari hasil interaksi dapat dijelaskan, bahwa suatu interaksi bersifat menguatkan terjadi jika pengaruh antara variabel independen $(X)$ dengan variabel moderator terhadap variabel dependen $(Y)$ bertanda positif. Sebaliknya satu interaksi melemahkan terjadi jika pengaruh antar variabel independen dengan variabel moderator bertanda negatif.

\section{Hubungan Kepemilikan Manajerial dengan Pembayaran Dividen}

Pembayaran dividen akan menjadi alat monitoring sekaligus bonding bagi manajemen (Mahaduarta dan Hartono 2002). Pembagian dividen akan membuat pemegang saham mempunyai tambahan return selain dari capital gain. Dividen ini juga membuat pemegang saham mempunyai kepastian pendapatan dan mengurangi agency cost of equity karena tindakan perquisites. Perquisites adalah tindakan manajemen yang memunculkan aliran kas keluar dalam rangka untuk tujuan bukan kepentingan perusahaan. Jensen dan Meckling (1976) mengemukan teori keagenan untuk mengurangi agency cost dengan penambahan kepemilikan manajerial, untuk mensejajarkan kepentingan manajer dan pemegang saham yang sering bertentangan.

Crutchley dan Hansen (1989) mengemukakan kepemilikan saham perusahaan oleh manajer yang tinggi mereka akan memiliki posisi kuat untuk melakukan tindakan menguasai terhadap perusahaan. Diasumsi bahwa manajer bertindak untuk memaksimalkan kepentingan diri sendiri, maka dengan informasi asimetri yang dimilikinya akan mendorong agent untuk menyembunyikan beberapa informasi yang tidak diketahui principal. Principal-agent problem muncul ketika terdapat asymmetric information (Ross 1973).

Mahadwartha dan Hartono (2002) mengemukakan semakin besar proporsi kepemilikan manajemen dalam perusahaan maka manajemen 
akan berusaha lebih giat untuk kepentingan pemegang saham yang notabene adalah mereka sendiri. Sesuai dengan Nam et al. (2004), Brown et al. (2004), Blouin et al (2004), serta Chetty dan Saez (2004), Ahmad Fauz dan Rosidi (2007) menemukan bahwa kepemilikan manajerial menunjukkan pengaruh positif terhadap kebijakan dividen, yang mengindikasikan bahwa perusahaan yang memiliki prosentase kepemilikan manajerial yang besar akan membagikan dividen yang besar. Hipotesa penelitian yang diajukan adalah:

$H_{1}$ : Kepemilikan manajerial berpengaruh signifikan terhadap kebijakan pembayaran dividen perusahaan.

\section{Penurunan Tarif PPh Dividen WPOP dalam Negeri dan Pembayaran Dividen}

Penurunan tarif $\mathrm{PPh}$ dividen WPOP dalam negeri dari sebesar $15 \%$ bersifat tidak final menjadi sebesar $10 \%$ bersifat final. Yang berlaku mulai 1 Januari 2009, diatur dalam Peraturan Pemerintah No. 19 Tahun 2009. Perubahan dan penurunan tarif tersebut akan mengurangi beban pajak WPOP dalam negeri sampai dengan $25 \%$ jika dibandingkan dari peraturan sebelumnya. Mengingat UU PPh di Indonesia menganut classical system, apabila WPOP sebagai pemilik atau pemegang saham, maka WPOP akan menanggung beban pajak yang meliputi pemajakan tingkat perusahaan atas laba dan pemajakan di tingkat orang pribadi atas dividen yang diterima (Sijbren Cnossen dalam Mansury 1996:43).

Tingginya tarif $\mathrm{PPh}$ dividen WPOP menyebabkan berkurangnya keuntungan investasi pemegang saham dan menghalangi perusahaan untuk membagi dividennya. Litzenberger dan Ramaswamy (1979), teori preferensi pajak mengemukakan bahwa selama dividen memiliki tarif pajak yang tinggi bagi investor dibandingkan dengan capital gain, maka teori ini menyarankan bahwa perusahaan sebaiknya menentukan dividend payout ratio yang rendah atau bahkan tidak membagikan dividen. Sedangkan Feldstein (1970), Jensen (1986) dan LaPorta et al. (2000), mengemukakan bahwa pajak dividen akan mengurangi keuntungan bersih investasi dan mengurangi investasi. Maka ketika pajak atas penghasilan dividen dipotong, orang pribadi lebih bersedia untuk menyimpan dan menginvestasikan uang mereka dalam bentuk saham untuk meningkatkan investasi.

Penurunan tarif $\mathrm{PPh}$ dividen WPOP menjadi alasan efisiensi biaya $\mathrm{PPh}$ kena pajak orang pribadi. Beberapa penelitian menfokuskan pada kepemilikan manajerial, hal ini disebabkan ketika managerial dikenakan tarif pajak lebih tinggi untuk penghasilan dividen mereka tidak memiliki insentif untuk meningkatkan dividen untuk keuntungan mereka sendiri. Namun, setelah ada penurunan tarif $\mathrm{PPh}$ dividen orang pribadi, managerial perusahaan yang memiliki saham besar dapat memanfaatkan dividen sebagai salah satu cara yang untuk mendistribusikan laba perusahaan dan meningkatkan kekayaan pribadi. Nam et al. (2004), Brown et al. (2004), Blouin et al (2004), serta Chetty dan Saez (2004), telah dibuktikan secara empiris bahwa kepemilikan manajerial mempunyai pengaruh positif dan signifikan terhadap kebijakan pembayaran dividen setelah adanya penurunan tarif $\mathrm{PPh}$ dividen WPOP. Hipotesa penelitian yang diajukan adalah:

$\mathrm{H}_{2}$ : Penurunan tarif $\mathrm{PPh}$ dividen WPOP dalam negeri memoderasi pengaruh kepemilikan manajerial terhadap kebijakan pembayaran dividen perusahaan.

\section{Model Penelitian}

Berdasarkan rumusan masalah, tujuan penelitian, kajian teoritis, dan review terhadap hasil riset-riset empiris, maka disusun kerangka konseptual seperti pada Gambar 1.

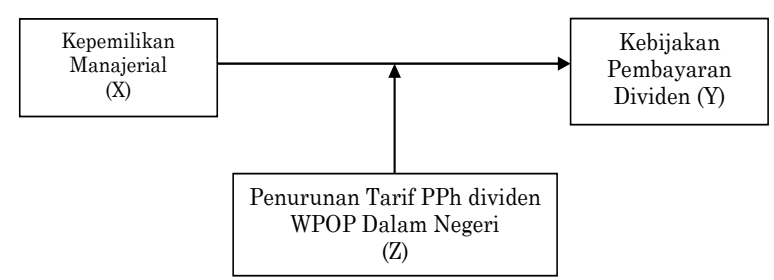

Gambar 1. Kerangka Konseptual Penelitian

\section{METODE PENELITIAN}

\section{Populasi dan Sampel}

Target populasi penelitian ini adalah seluruh perusahaan yang terdaftar di Bursa Efek Indonesia mulai tahun 2007 hingga 2009 yang memenuhi kriteria sebagai berikut: (a) Perusahaan terdaftar di Bursa Efek Indonesia mulai dari tahun 2007 sampai dengan 2009; (b) Perusahaan membayarkan dividen minimal setahun sekali secara berturut-turut mulai tahun 2007 hingga tahun 2009; (c) Kepemilikan saham oleh pihak manajemen (kepemilikan manajerial); dan (d) Perusahaan memberikan data laporan keuangan secara lengkap, sesuai dengan variabel penelitian periode tahun 2007 hingga tahun 2009. Berdasarkan kriteria tersebut terdapat 44 perusahaan yang menjadi target populasi. Dengan menggunakan data selama dua tahun maka jumlah sampel dalam penelitian ini adalah 88 tahun perusahaan. 


\section{Definisi Operasional Variabel}

Variabel dependen adalah kebijakan pembayaran dividen, yaitu keputusan yang diambil oleh perusahaan tentang pembagian keuntungan bersih kepada pemegang saham dalam bentuk dividen kas. Kebijakan pembayaran dividen (Dividen ${ }_{i t}$ = dividen per lembar saham perusahaan $i$ pada periode $t$ (Divit) dikurangi dividen per lembar saham perusahaan $i$ pada periode $t$ dikurangi periode $t-1$ (Divit-1) dibagi dividen per lembar saham perusahaan $i$ pada periode $t$ dikurangi periode $t$-1(Divit-1). Apabila selisih positif dikategorikan dividen meningkat diberi kode 1 (satu) dan selisih minus atau nol dikategorikan dividen menurun diberi kode 0 (nol).

Variabel independen adalah Kepemilikan Manajerial (Managerial Ownership), yaitu kepemilikan saham oleh dewan komisaris, dewan direksi dan manajer yang aktif ikut dalam pengambilan keputusan. Sesuai Blouin et al. (2004) kepemilikan saham diukur dengan proporsi saham yang dimiliki Dewan Direksi dan Komisaris perusahaan pada akhir tahun dan dinyatakan dalam prosentase. Kepemilikan manajerial perusahaan $i$ pada periode $t\left(M o w n_{i t}\right)=$ Jumlah saham yang dimiliki oleh direksi dan komisaris perusahaan $i$ pada periode $t$ (Managerialstockit) dibagi Jumlah total saham perusahaan yang beredar perusahaan $i$ pada periode $t$ (Totstockit).

Variabel moderator yaitu Penurunan tarif $\mathrm{PPh}$ dividen WPOP dalam negeri menggunakan variabel dummy untuk menunjukan adanya penurunan tarif $\mathrm{PPh}$ dividen WPOP dalam negeri dari tarif $15 \%$ bersifat tidak final menjadi $10 \%$ bersifat final, yang mulai berlaku 1 Januari 2009. Sesuai dengan Nam et al. (2004) dan Blouin et al. (2004) maka kebijakan penurunan tarif $\mathrm{PPh}$ dividen WPOP dalam negeri, diberi kode 0 (nol) sebelum ada kebijakan penurunan tarif $\mathrm{PPh}$ dividen WPOP dalam negeri dan diberi kode 1 (satu) setelah ada kebijakan penurunan tarif $\mathrm{PPh}$ dividen WPOP dalam negeri.

Variabel kontrol dalam penelitian ini:

a. Rasio hutang (Debt ratio) diukur dengan menggunakan rasio total hutang jangka panjang terhadap total aset. $D E B T_{i t}=$ Jumlah hutang jangka panjang perusahaan $i$ pada periode $t$ $\left(L T D_{i t}\right)$ dibagi Total asset yang dimiliki perusahaan $i$ pada periode $t$ (Total Asset ${ }_{i}$ )

b. Ukuran perusahaan (Size) dapat diukur dengan menggunakan natural log total asset. $S I Z E_{i t}=L n$ Total aset yang dimiliki perusahaan $i$ pada periode $t$

c. Market to book Ratio dihitung berdasarkan rasio dari perkalian harga saham pada pe- nutupan akhir tahun dengan jumlah seluruh saham beredar nilai total ekuitas pada akhir tahun. Market to book value perusahaan $i$ pada akhir periode $t\left(M T B V_{i t}\right)=$ jumlah seluruh saham beredar perusahaan $i$ pada akhir periode $t$ (Tot. Share it) dikali closing price akhir tahun perusahaan $i$ pada periode $t$ (Cls Priceit) dibagi nilai ekuitas perusahaan $i$ pada akhir periode $t$ (Common Equityit)

d. Arus kas bersih (Net Cash Flow) adalah arus kas bersih dari aktivitas operasi dengan total aset. Net cash flow perusahaan $i$ pada akhir periode $t\left(N E T C F_{\mathrm{it}}\right)=$ arus kas bersih dari aktivitas operasi perusahaan $i$ pada akhir periode $t$ (Net operating cash flowit) dibagi total aset akhir tahun perusahaan $i$ pada periode $t$ (Total Asset $\left.{ }_{i t}\right)$

e. Kas (Cash) adalah Cash holding: uang tunai ditangan dan total investasi jangka pendek dengan total aset. Uang tunai ditangan perusahaan $i$ pada akhir periode $t\left(\right.$ Cash $\left._{\mathrm{it}}\right)=$ uang tunai perusahaan $i$ pada akhir periode $t$ (Cash $i t)$ dijumlah total investasi jangka pendek perusahaan $i$ pada akhir periode $t$ (Short-term investmentit) dibagi total aset akhir tahun perusahaan $i$ pada periode $t$ (Total Asset ${ }_{i t}$ )

\section{HASIL PENELITIAN DAN PEMBAHASAN}

\section{Deskripsi Data}

Berdasarkan data dari ICMD maka diperoleh data kebijakan pembayaran dividen, kepemilikan manajerial, kebijakan hutang, ukuran perusahaan, market to book ratio, arus kas bersih, dan kas. Selanjutnya apabila dilihat dari nilai minimum, maksimum, rata-rata (mean) dan standar deviasi (ठ) dari masing-masing variabel penelitian dapat dilihat pada Tabel 1.

Berdasarkan hasil perhitungan pada Tabel 1 tersebut ada 44 perusahaan sampel dengan data pengamatan (44 perusahaan $\mathrm{x} 2$ tahun $=88$ pengamatan). Rata-rata kepemilikan manajerial sebesar 5,2743 dengan standar deviasi (SD) sebesar 11,2551. Rata-rata hutang perusahaan 0,1168 dengan standar deviasi 0,1463 . Untuk variabel ukuran perusahaan diperoleh nilai ratarata 28,7735 dengan standar deviasi 2,0372. Kemudian untuk variabel market to book ratio diperoleh nilai rata-rata 2,3897 dengan standar deviasi 4,2005. Untuk variabel arus kas diperoleh nilai rata-rata 0,1177 dengan standar deviasi 0,1316. Sedangkan untuk variabel kas diperoleh nilai rata-rata 0,1449 dengan standar deviasi 0,1593 . 
Tabel 1. Perhitungan Minimum, Maksimum, Mean, Median, Standar Deviasi

\begin{tabular}{|c|c|c|c|c|c|}
\hline & $\mathrm{N}$ & Min & $\operatorname{Max}$ & Mean & SD \\
\hline Kepemilikan manajerial & 88 & 0.0000 & 54.3780 & 5.2743 & 11.2551 \\
\hline Kebijakan Hutang & 88 & 0.0001 & 0.5832 & 0.1168 & 0.1463 \\
\hline Ukuran perusahaan & 88 & 24.8500 & 33.2700 & 28.7735 & 2.0372 \\
\hline Market to book ratio & 88 & 0.1100 & 26.9000 & 2.3897 & 4.2005 \\
\hline Arus kas bersih & 88 & -0.1500 & 0.5600 & 0.1177 & 0.1316 \\
\hline Kas & 88 & 0.0005 & 0.7927 & 0.1449 & 0.1593 \\
\hline
\end{tabular}

Sumber: Data Sekunder, ICMD 2007-2009 diolah

Tabel 2. Ringkasan Hasil Regresi Logistik Untuk Pengujian Hipotesis

\begin{tabular}{|c|c|c|c|}
\hline Variabel & Model 1 & Model 2 & Model 3 \\
\hline \multirow[t]{2}{*}{ Mown } & 1.124 & 0.778 & 1.455 \\
\hline & $0.001^{*}$ & $0.008^{*}$ & $0.048^{*}$ \\
\hline $\operatorname{Exp}(\beta)$ & 3.079 & 2.177 & 4.284 \\
\hline \multirow[t]{2}{*}{ Mown by Tax } & - & 9.436 & 18.711 \\
\hline & & $0.020^{*}$ & $0.032 *$ \\
\hline $\operatorname{Exp}(\beta)$ & & 12534.955 & $1.30 \mathrm{E}+08$ \\
\hline \multirow[t]{2}{*}{ Debt } & - & - & $(24.952)$ \\
\hline & & & 0.062 \\
\hline $\operatorname{Exp}(\beta)$ & & & 0.000 \\
\hline \multirow[t]{2}{*}{ Size } & - & - & 0.408 \\
\hline & & & 0.298 \\
\hline $\operatorname{Exp}(\beta)$ & & & 1.504 \\
\hline \multirow[t]{2}{*}{$M T B$} & - & - & $(0.054)$ \\
\hline & & & 0.648 \\
\hline $\operatorname{Exp}(\beta)$ & & & 0.948 \\
\hline \multirow[t]{2}{*}{ Netcash } & - & - & 17.515 \\
\hline & & & $0.041^{*}$ \\
\hline $\operatorname{Exp}(\beta)$ & & & $4.0 \mathrm{E}+07$ \\
\hline \multirow[t]{2}{*}{ Cash } & - & - & $(0.663)$ \\
\hline & & & 0.887 \\
\hline $\operatorname{Exp}(\beta)$ & & & 0.515 \\
\hline \multirow[t]{2}{*}{ Constant } & (1.395) & (1.906) & (13.919) \\
\hline & 0.000 & 0.000 & 0.244 \\
\hline$R^{2}$ & 0.622 & 0.720 & 0.899 \\
\hline \multirow[t]{2}{*}{ Hosmer and Lomeshow test } & 43.003 & 13.937 & 0.997 \\
\hline & 0.000 & 0.052 & 0.995 \\
\hline
\end{tabular}

Sumber: Data Sekunder, ICMD 2007 - 2009 diolah

* signifikan pada level $5 \%$

\section{Pengujian Hipotesis dan diskusi}

Terdapat dua hipotesis yang diuji, yaitu hipotesis pertama kepemilikan manajerial berpengaruh signifikan terhadap kebijakan pembayaran dividen perusahaan, hipotesis kedua penurunan tarif $\mathrm{PPh}$ dividen WPOP dalam negeri memoderasi pengaruh kepemilikan manajerial terhadap kebijakan pembayaran dividen perusahaan dan pengaruh variabel kontrol yang terdiri kebijakan hutang (DEBT), ukuran perusahaan (Size), market to book ratio, arus kas bersih (Netcash), dan kas (Cash) pada hasil penelitian. Pembuktian hipotesis dengan uji Wald, tujuannya untuk mengetahui pengaruh masing-masing variabel bebas terhadap variabel tergantung dalam satu model.
Berdasarkan hasil penelitian dan analisis yang telah dilakukan maka dihasilkan model regresi logistik dapat dilihat pada Tabel 2.

\section{Pengujian Hipotesis 1}

Hipotesis pertama yang menyatakan bahwa kepemilikan manajerial mempunyai pengaruh terhadap kebijakan pembayaran dividen perusahaan, pada hasil analisis regresi logistik Tabel 2 model 1 di atas dengan model prediksi kebijakan pembayaran dividen adalah:

$$
\operatorname{Ln}(\text { Dividen })=1,395+1,124 X_{1}
$$

Dari Tabel 2 diketahui nilai koefisien regresi logistik variabel kepemilikan manajerial 1,124 dan 
bertanda positif artinya jika variabel bebas kepemilikan manajerial dinaikan sebesar 1 unit, secara rata-rata estimated logit naik sebesar $e^{-(1,124)}$. Nilai signifikansi $0,001(p<0,05)$ atau signifikansinya lebih kecil dari 0,05 maka ada pengaruh signifikan kepemilikan manajerial terhadap kebijakan pembayaran dividen perusahaan. Nilai odd rasio 3,079 artinya faktor resiko terjadinya peningkatan pembayaran dividen pada perusahaan yang kepemilikkan manajerial tinggi adalah 3,079 kali lebih besar dibandingkan dengan kepemilikan manajerial rendah.

Nilai Nagelkerke $R$ Square adalah 0,622 yang berarti variabel kebijakan pembayaran dividen yang dapat dijelaskan oleh variabel kepemilikan manajerial sebesar $62,2 \%$. Sedangkan sisanya sebesar $37,8 \%$ dipengaruhi oleh variabel lain diluar variabel-variabel yang digunakan dalam penelitian ini. Sedangkan uji kesesuian model 1 diketahui dari nilai Hosmer and Lomeshow test 43,003 memiliki signifikansi 0,000 yang menunjukkan $H_{0}$ ditolak karena nilai signifikansi dikurang 0,05. Tabel 3 model 1 dapat diketahui bahwa pada kolom prediksi dividen menurun adalah 44, sedangkan hasil observasi adalah 45, jadi tingkat keakuratan analisis regresi logistik dalam memprediksi yaitu sebesar 97,8\%. Prediksi dividen meningkat suatu perusahaan adalah 12 , sedangkan hasil observasi sejumlah 43 sehingga ketepatan klasifikasi sebesar 72,1\%. Model ini secara keseluruhan mampu memprediksi dengan tingkat keakuratan sebesar $85,2 \%$.

Variabel kepemilikan manajerial berpengaruh positif terhadap kebijakan pembayaran dividen perusahaan, yang mengindikasikan bahwa perusahaan yang memiliki prosentase kepemilikkan manajerial yang tinggi berpengaruh pada pengingkatan kebijakan pembayaran dividen perusahaan. Hal ini sesuai Mahadwartha dan Hartono (2002) semakin besar proporsi kepemilikan manajemen dalam perusahaan maka manajemen akan berusaha lebih giat untuk kepentingan pemegang saham yang notabene adalah mereka sendiri. Kepemilikan saham perusahaan oleh manajer yang tinggi akan dapat menimbulkan entrenchment problem, Crutchley dan Hansen (1989). Apabila kepemilikan saham perusahaan oleh manajer relatif besar, mereka akan memiliki posisi kuat untuk melakukan kontrak terhadap perusahaan.

Dari hasil pengujian hipotesis model 1 dapat disimpulkan bahwa hipotesis yang menyatakan bahwa kepemilikan manajerial mempunyai pengaruh positif dan signifikan terhadap kebijakan pembayaran dividen perusahaan. Sesuai dengan penelitian Nam et al. (2004), Chetty dan Saez (2004), Brown et al. (2004) serta Blouin et al.
(2004) menemukan hasil bahwa managerial ownership mempunyai pengaruh positif dan signifikan terhadap peningkatan kebijakan pembayaran dividen. Namun hasil berbeda ditunjukan dalam penelitian Ismiyanti (2003) dan Suwaldiman (2006) menguji kepemilikan manajerial terhadap kebijakan dividen menemukan hubungan negatif tetapi tidak signifikan terhadap kebijakan dividen.

\section{Pengujian Hipotesis 2}

Hipotesis kedua menyatakan bahwa penurunan tarif $\mathrm{PPh}$ dividen WPOP dalam negeri memoderasi pengaruh kepemilikan manajerial terhadap kebijakan pembayaran dividen perusahaan, hasil regresi logistik dapat dilihat pada Tabel 2 model 2 dengan model prediksi kebijakan pembayaran dividen adalah:

$$
\operatorname{Ln}(\text { Dividen })=1,906+0,778 X_{1}+9,436 X_{1} * Z
$$

Nilai koefisien regresi logistik variabel kepemilikan manajerial adalah sebesar 0,778 dengan nilai signifikansi 0,008 maka dapat disimpulkan bahwa kepemilikan manajerial mempunyai pengaruh positif dan signifikan terhadap kebijakan pembayaran dividen perusahaan. Nilai odd ratio 2,177 artinya faktor resiko terjadinya peningkatan pembayaran dividen pada perusahaan yang mempunyai kepemilikan manajerial tinggi adalah 2,177 kali lebih besar dibandingkan dengan kepemilikan manajerial rendah. Interaksi antara variabel kepemilikan manajerial dengan variabel penurunan tarif $\mathrm{PPh}$ dividen WPOP dalam negeri terhadap variabel kebijakan pembayaran dividen perusahaan memiliki koefisien regresi 9.436 dengan nilai signifikansi 0,020 . Nilai odd ratio 12534.955 artinya faktor resiko terjadinya peningkatan pembayaran dividen pada perusahaan yang mempunyai kepemilikan manajerial tinggi dan pada saat terjadi kebijakan penurunan tarif pajak $\mathrm{PPh}$ dividen WPOP dalam negeri adalah 12534,955 kali lebih besar dibandingkan dengan kepemilikan manajerial rendah dan tidak terjadi penurunan tarif pajak PPh dividen WPOP dalam negeri.

Nilai Nagelkerke $R$ Square adalah 0,720 yang berarti variabel kebijakan pembayaran dividen yang dapat dijelaskan oleh variabel kepemilikan manajerial sebesar $72 \%$. Sedangkan sisanya sebesar 28\% dipengaruhi oleh variabel lain diluar variabel-variabel bebas yang digunakan dalam penelitian ini. Chi-Square Hosmer and Lomeshow 13,937, nilai signifikansi 0,052 yang menunjukkan $H_{0}$ diterima karena nilai signifikansi lebih dari 0,05 . Uji ini menyimpulkan bahwa model tersebut layak dan dapat diterima. 
Tabel 3. Ringkasan Tabel Klasifikasi Hasil Prediksi Regresi Logistik

\begin{tabular}{|c|c|c|c|c|c|c|c|c|c|}
\hline \multirow{4}{*}{ Observasi } & \multicolumn{9}{|c|}{ Prediksi } \\
\hline & \multicolumn{3}{|c|}{ Model 1} & \multicolumn{3}{|c|}{ Model 2} & \multicolumn{3}{|c|}{ Model 3} \\
\hline & Divide & n Relatif & & Divide & n Relatif & & Divide & n Relatif & \\
\hline & $\begin{array}{c}\text { dividen } \\
\text { menu- } \\
\text { run }\end{array}$ & $\begin{array}{c}\text { dividen } \\
\text { mening- } \\
\text { kat }\end{array}$ & $\%$ & $\begin{array}{c}\text { dividen } \\
\text { menu- } \\
\text { run }\end{array}$ & $\begin{array}{c}\text { dividen } \\
\text { mening- } \\
\text { kat }\end{array}$ & $\%$ & $\begin{array}{c}\text { dividen } \\
\text { menu- } \\
\text { run }\end{array}$ & $\begin{array}{c}\text { dividen } \\
\text { mening- } \\
\text { kat }\end{array}$ & $\%$ \\
\hline Dividen relatif Dividen menurun & 44 & 1 & 97.8 & 43 & 2 & 95.6 & 43 & 2 & 95.6 \\
\hline Dividen meningkat & 12 & 31 & 72.1 & 7 & 36 & 83.7 & 3 & 40 & 93 \\
\hline Overall Percentage & & & 85.2 & & & 89.8 & & & 94.3 \\
\hline
\end{tabular}

Sumber: Data Sekunder, ICMD 2007- 2009 diolah.

Tabel 3 model 2 dapat diketahui bahwa pada kolom prediksi yang dividen menurun adalah 43, sedangkan hasil observasi adalah 45, jadi tingkat keakuratan analisis regresi logistik dalam memprediksi yaitu sebesar 95,6\%. Prediksi dividen meningkat adalah 7 , sedangkan hasil observasi sejumlah 43 sehingga ketepatan klasifikasi sebesar 83,7\%. Model ini secara keseluruhan mampu memprediksi dengan tingkat keakuratan sebesar $89,8 \%$.

Interaksi variabel penurunan tarif $\mathrm{PPh}$ dividen WPOP dalam negeri dengan kepemilikan manajerial memiliki koefisien regresi 9,436 dengan nilai signifikansi 0.020 yang artinya berpengaruh positif terhadap model. Hasil penelitian yang positif dan signifikan mengindikasikan bahwa tarif $\mathrm{PPh}$ dividen WPOP dalam negeri turun maka pengaruh kepemilikan manajerial terhadap kebijakan pembayaran dividen perusahaan akan semakin kuat. Dapat disimpulkan bahwa penurunan tarif $\mathrm{PPh}$ dividen WPOP dalam negeri memoderasi pengaruh kepemilikan manajerial terhadap kebijakan pembayaran dividen perusahaan. Hasil ini sesuai dengan Nam et al. (2004), Brown et al. (2004), Blouin et al. (2004) serta Chetty dan Saez (2004), menyatakan bahwa penurunan tarif $\mathrm{PPh}$ dividen WPOP mendorong para manajer perusahaan yang memilik saham besar dengan memanfaatkan dividen sebagai salah satu cara untuk mendistribusikan laba perusahaan dan meningkatkan kekayaan pribadi. Yang artinya ketika para manajer dikenakan tarif pajak lebih rendah untuk penghasilan dividen, dibandingkan dengan pajak capital gain, mereka memiliki insentif untuk meningkatkan dividen untuk keuntungan mereka sendiri.

Ketika tarif $\mathrm{PPh}$ dividen WPOP dalam negeri turun dari sebesar $15 \%$ bersifat tidak final menjadi sebesar $10 \%$ bersifat final maka WPOP dalam negeri akan mendapatkan insentif berupa pengurangan beban pajak sampai dengan 25\% jika dibandingkan dari peraturan sebelumnya. Mengingat di Indonesia UU PPh menganut classical system, sesuai dengan Pasal 4 ayat 1 dan ayat 2
Undang-Undang Nomor 7 Tahun 1983 sebagaimana telah diubah terakhir dengan UndangUndang Nomor 36 Tahun 2008 tentang PPh, atas penghasilan yang bersumber dari perusahaan akan dikenakan $\mathrm{PPh}$ pada tingkat perusahaan dan pada tingkat pemilik atau pemegang saham dikenakan pajak pada saat pendistribusian dividen.

Nam et al. (2004), Brown et al. (2004) serta Chetty dan Saez (2004), menemukan hubungan principal-agent, antara kepemilikan manajerial dengan kebijakan pembayaran dividen dengan adanya penurunan tarif $\mathrm{PPh}$ dividen WPOP. Principal-agent problem muncul ketika terdapat asymmetric information, yang berkaitan dengan kegiatan maupun informasi yang dimiliki oleh seorang agen, Ross (1973). Dengan asumsi bahwa orang pribadi-orang pribadi bertindak untuk memaksimalkan kepentingan diri sendiri, maka dengan informasi asimetri yang dimilikinya akan mendorong agent untuk menyembunyikan beberapa informasi yang tidak diketahui principal. Teori keagenan mengatakan bahwa mekanisme dividen menyediakan insentif bagi manajer untuk menurunkan biaya yang berkaitan dengan hubungan principal/agen dengan cara meningkatkan pembayaran dividen, Rozeff (1982).

\section{Pengaruh Variabel Kontrol pada Hasil Penelitian}

Model 3 adalah pengujian regresi logistik dengan mengikutsertakan variabel kontrol yaitu kebijakan hutang, ukuran perusahaan, market to book ratio, arus kas bersih, dan kas. Model prediksi kebijakan pembayaran dividen yang dihasilkan Tabel 2 model 3 diatas adalah:

$$
\begin{aligned}
\operatorname{Ln}(\text { Dividen })= & 13919+1,455 X_{1}+18711\left(X_{1}^{*} Z\right)- \\
& 24952 X_{2}+0,408 X_{3-} 0,054 X_{4}+ \\
& 17,51 X_{5}-0,663 X_{6}
\end{aligned}
$$

Dari Tabel 2 model 3 diketahui variabel kepemilikan manajerial terhadap variabel kebijakan pembayaran dividen memiliki koefisien 
regresi 1,455 dengan nilai signifikansinya 0,048, artinya kepemilikan manajerial mempunyai pengaruh positif dan signifikan terhadap kebijakan pembayaran dividen perusahaan. Nilai odd rasio 4,284 artinya faktor resiko terjadinya kebijakan pembayaran dividen pada perusahaan yang kepemilikan manajerialnya tinggi adalah 4,284 kali lebih besar dibandingkan dengan kepemilikan manajerial rendah.

Interaksi antara variabel kepemilikan manajerial dengan variabel penurunan tarif $\mathrm{PPh}$ dividen WPOP terhadap variabel kebijakan pembayaran dividen memiliki koefisien regresi 18,711 dengan nilai signifikansi 0,032, artinya penurunan tarif $\mathrm{PPh}$ dividen WPOP dalam negeri memoderasi pengaruh kepemilikan manajerial terhadap kebijakan pembayaran dividen. Nilai odd rasio $1.3 E+08$, artinya faktor resiko terjadinya peningkatan pembayaran dividen pada perusahaan yang mempunyai kepemilikan manajerial tinggi dan pada saat terjadi kebijakan penurunan tarif pajak $\mathrm{PPh}$ dividen WPOP dalam negeri adalah $1.3 \mathrm{E}+08$ kali lebih besar dibandingkan dengan kepemilikan manajerial rendah dan tidak terjadi penurunan tarif pajak PPh dividen WPOP dalam negeri.

Variabel kebijakan hutang terhadap variabel kebijakan pembayaran dividen memiliki koefisien regresi -24,952 dengan nilai signifikansi 0,062 dan nilai odd rasio 0,000 artinya faktor yang menghambat terjadinya kebijakan pembayaran dividen pada perusahaan yang mempunyai kebijakan hutang tinggi adalah 0,000 kali lebih kecil dibandingkan dengan kebijakan hutang rendah. Variabel kebijakan hutang pengaruh negatif dan tidak signifikan. Hasil ini sesuai dengan Nam et al. (2004), Brown et al. (2004), Chetty dan Saez (2004) kebijakan hutang menunjukkan pengaruh negatif terhadap kebijakan pembayaran dividen.

Variabel ukuran perusahaan terhadap kebijakan pembayaran dividen memiliki koefisien regresi 0,408 dengan nilai signifikansi 0,298 . Nilai odd rasio 1,504 artinya faktor resiko terjadinya kebijakan pembayaran dividen pada perusahaan yang mempunyai ukuran perusahaan tinggi adalah 1,504 kali lebih besar dibandingkan dengan ukuran perusahaan rendah. Varibel ukuran perusahaan berpengaruh positif dan tidak signifikan terhadap kebijakan pembayaran dividen perusahaan. Hasil ini sesuai dengan penelitian yang dilakukan oleh Nam et al. (2004), dan Blouin et al. (2004) menemukan hubungan positif antara ukuran perusahaan dengan kenaikan kebijakan pembayaran dividen.

Variabel market to book ratio terhadap kebijakan pembayaran dividen memiliki koefisien regresi -0,054 dengan nilai signifikansi 0,648 dan nilai odd rasio 0,948 artinya faktor penghambat terjadinya kebijakan pembayaran dividen pada perusahaan yang mempunyai market to book ratio tinggi adalah 0,948 kali lebih kecil dibandingkan dengan market to book ratio rendah. Variabel market to book ratio berpengaruh negatif dan tidak signifikan. Hasil ini sesuai dengan penelitian yang dilakukan Nam, et al. (2004), Brown, et al. (2004), Blouin, et al. (2004), market to book ratio menunjukkan pengaruh negatif dan tidak signifikan dengan peningkatan dividen. Nam, et al. (2004), market to book ratio digunakan sebagai proksi kesempatan investasi. Alasan penggunaan proksi tersebut yaitu semakin besar peluang investasi suatu perusahaan maka secara umum semakin besar pula nilai pasarnya yang berhubungan dengan nilai bukunya

Variabel arus kas bersih terhadap kebijakan pembayaran dividen memiliki koefisien regresi 17,515 dengan nilai signifikansi 0,041 dan nilai odd rasio $4.0 E+07$ artinya faktor resiko terjadinya kebijakan pembayaran dividen pada perusahaan yang mempunyai arus kas bersih tinggi adalah 4.0E+07 kali lebih besar dibandingkan dengan perusahaan yang mempunyai arus kas bersih rendah. Variabel arus kas bersih berpengaruh positif dan signifikan. Hasil ini sesuai dengan penelitian Nam, et al. (2004), Blouin, et al. (2004), Brown, et al. (2004), variabel arus kas bersih berpengaruh positif dan signifikan terhadap peningkatan dividen. Hal ini menunjukkan bahwa perusahaan dengan arus kas bersih tinggi lebih meningkatkan dividen.

Variabel kas terhadap kebijakan pembayaran dividen memiliki koefisien regresi 0,663 dengan nilai signifikansi 0,887 dan nilai odd rasio 0,515 arti faktor penghambat resiko terjadinya kebijakkan pembayaran dividen pada perusahaan yang mempunyai kas tinggi adalah 0,515 kali lebih kecil dibandingkan dengan kas rendah. Variabel kas berpengaruh negatif dan tidak signifikan. Hasil ini sesuai dengan penelitian yang dilakukan. Nam, et al. (2004), Chetty dan Saez (2004), dan Brown, et al. (2004), menemukan kas berpengaruh negatif dan tidak signifikan terhadap peningkatan dividen. Ini menunjukan bahwa saldo kas dalam jumlah besar perusahaan tidak berpengaruh meningkatkan dividen.

Nilai Nagelkerke $R$ Square adalah 0,899 yang berarti variabel dependen yang dapat dijelaskan oleh variabel independen sebesar $89,9 \%$. Sedangkan sisanya sebesar $10,10 \%$ dipengaruhi oleh variabel lain diluar variabel-variabel bebas yang digunakan dalam penelitian ini. Nilai Chi-Square Hosmer and Lomeshow sebesar 0.997 memiliki signifikansi sebesar 0,995 yang menunjukkan Ho diterima karena nilai signifikansi lebih dari 0,05. Uji ini menyimpulkan bahwa model tersebut layak dan dapat diterima. 
Tabel 3 model 3 dapat diketahui bahwa pada kolom prediksi dividen menurun adalah 43, sedangkan hasil observasi adalah 45, jadi tingkat keakuratan analisis regresi logistik dalam memprediksi yaitu sebesar 95.6\%. Prediksi dividen meningkat adalah 3, sedangkan hasil observasi sejumlah 43 sehingga ketepatan klasifikasi sebesar 93\%. Model ini secara keseluruhan mampu memprediksi dengan tingkat keakuratan sebesar $94,3 \%$.

Hasil pengujian model 1, model 2 dan model 3 diketahui bahwa variabel kepemilikan manajerial berpengaruh terhadap kebijakan pembayaran dividen perusahaan dan ketika kepemilikan manajerial diinteraksikan dengan penurunan tarif $\mathrm{PPh}$ dividen WPOP dalam negeri maupun diikutkannya variabel kontrol tetap berpengaruh positif dan signifikan, yang mengindikasikan bahwa tarif $\mathrm{PPh}$ dividen WPOP dalam negeri turun maka pengaruh kepemilikan manajerial terhadap kebijakan pembayaran dividen perusahaan akan semakin kuat. Bahwa faktor tarif $\mathrm{PPh}$ dividen wajib pajak orang pribadi dalam negeri tetap berpengaruh dalam kebijakan pembayaran selain faktor keuangan perusahaan, sesuai dengan Nam et al. (2004) menjelaskan selain faktor pajak, faktor keuangan perusahaan juga mempengaruhi kebijakan pembayaran dividen.

\section{KESIMPULAN DAN SARAN}

\section{Kesimpulan}

Berdasarkan analisis dan hasil pembahasan dapat diambil kesimpulan sebagai berikut:

1. Kepemilikan manajerial berpengaruh positif dan signifikan terhadap kebijakan pembayaran dividen perusahaan. Hal tersebut mengindikasikan bahwa kepemilikan manajerial berpengaruh terhadap peningkatan kebijakan pembayaran dividen perusahaan.

2. Interaksi variabel kepemilikan manajerial dengan variabel penurunan tarif $\mathrm{PPh}$ dividen WPOP dalam negeri berpengaruh positif dan signifikan terhadap kebijakan pembayaran dividen perusahaan. Hal ini mengindikasikan bahwa penurunan tarif $\mathrm{PPh}$ dividen WPOP dalam negeri menguatkan kepemilikan manajerial terhadap kebijakan pembayaran dividen perusahaan, walaupun dengan mengikutkan variabel variabel kontrol yaitu kebijakan hutang, ukuran perusahaan, market to book ratio, arus kas bersih, dan kas. Sesuai dengan data dari BEI dari tahun 2007-2010 jumlah perusahaan yang membagi dividen terus mengalami peningkatan. Jika dibandingkan antara jumlah perusahaan yang terdaftar dan yang membagi dividen mulai tahun 2007 (39,95\%), tahun 2008 (42,21\%), tahun 2009 (46,19\%) dan tahun 2010 (46,19\%). Dari data tersebut pada periode 2009 dan 2010 terdapat peningkatan pembayaran dividen. Bersamaan dengan perubahan peraturan atas tarif PPh WPOP dalam negeri mulai 01 Januari 2009.

\section{Saran}

1. Bagi Pemerintah: (a) Pemerintah agar tidak menaikkan atau merubah sifat pengenaan tarif $\mathrm{PPh}$ dividen wajib pajak orang pribadi dalam negeri sebesar 10\% dalam beberapa tahun kedepan untuk mengurangi beban pajak WPOP, (b) Mendorong perusahaan untuk mendistribusikan penghasilannya kepada pemegang saham daripada laba ditahan, pemerintah membuat aturan tentang jangka waktu laba ditahan perusahaan tertutup.

2. Bagi peneliti selanjutnya: Untuk mengetahui respon dari penurunan tarif $\mathrm{PPh}$ dividen WPOP dalam negeri maka; (a) Data tahun penelitian diperpanjang setelah periode tahun berlakunya penurunan tarif $\mathrm{PPh}$ dividen WPOP dalam negeri, (b) memasukkan kriteria perusahaan yang sebelum tahun 2008 tidak membagikan dividen dan kemudian membagikan dividen di tahun 2009 sehingga penelitian tidak harus perusahaan yang membagi secara berturut turut selama tahun 2008 dan tahun 2009, (c) Skop perusahaan diperluas ke perusahaan tertutup.

\section{DAFTAR PUSTAKA}

Blouin, J., Raedy, J., and D. Shackelford. (2004). The Initial Impact of the 2003 Reduction in the Dividend Tax Rate, University of North Carolina working paper.

Brown, J.R., Weisbenner, S., and Liang, N. (2004). Executive Financial Incentives and Payout Policy: Firm Responses to the 2003 Dividend Tax Cut, Journal of Finance, 62(4), 1935-1965.

Chetty, R. and Saez, E. (2004). Dividend taxes and Corporate Behavior: Evidence from the 2003 dividend tax cut. Quarterly Journal of Economics, 120(3), 791-833.

Crutchley, C.E. and Hansen, R.S. (1989). A Test of the Agency Theory of Managerial Ownership, Corporate Leverage, and Corporate Dividends, Financial Management, 36-46.

Fauz, A. dan Rosidi. (2007). Pengaruh Aliran Kas Bebas, Kepemilikan Manajerial, Kepemilikan Institusional, Kebijakan Utang dan Collateral Asset terhadap Kebijakan Dividen, Jurnal Ekonomi dan Manajemen, 8(2). 
Feldstein, M. (1970). Corporate Taxation and Dividend Behavior, Review of Economic Studies, 37, 57-72.

Ghozali, I. (2009). Aplikasi Analisis Multivariate dengan Program SPSS, Semarang: Badan Penerbit Universitas Diponegoro.

Harnanto. (2003). Akuntansi Perpajakan. Edisi Pertama, Yogyakarta, BPFE-Yogyakarta.

Ismiyanti, F. dan Hanafi, M. M. (2003). Kepemilikan Manajerial, Kepemilikan institusional, Risiko, Kebijakan Utang dan Kebijakan Dividen: Analisis Persamaan Simultan, Simposium Nasional Akuntansi VI, Surabaya, 16-17 Oktober 2003.

Jensen, M. C. and Meckling. W. (1976). The Theory of The Firm: Managerial Behavior, Agency Cost, and Ownership Structure, Journal of Financial Economics.

Jensen, M. C. (1986). Agency costs of free cash flow, corporate finance and takeovers, American Economic Review 76, 323-329.

LaPorta, R., Lopez-de-Silanes, F., Shleifer, A., and Vishny, R. (2000). Agency Problems and Dividend Policies Around the World, Journal of Finance, 55(1), 1-33.

Litzenberger, R.H. and Ramaswamy, K. (1979). The Effect of Personal Taxes and Dividends on Capital Asset Prices: Theory and Empirical Evidence, Journal of Financial Economics, June.

Mahadwartha, P. A. dan Hartono, J. (2002). Uji Teori Keagenan dalam Hubungan Interdependensi antara Kebijakan Hutang dan Kebijakan Dividen, Simposium Nasional Akuntansi V. Ikatan Akuntansi Indonesia (IAI). 635-647.

Mansury. (1996). Pajak Penghasilan Lanjutan. Cetakan Pertama: September 1996, Jakarta, Penerbit: Ind-Hill-Co.

Nam, J., Wang, J., and Zhang, G. (2004). The Impact of Dividend Tax Cut and Managerial Stock Holdings on Firm's Dividend Policy, Working Paper.

Putu, A. M. dan Jogiyanto, H. (2002). Uji Teori Keagenan Dalam Hubungan Interdependensi Antara Kebijakan Hutang dan Kebijakan Dividen, Makalah Seminar, Simposium Nasional Akuntansi V, Ikatan Akuntansi Indonesia, 635-647.

Ross, A. S. (1973). The Economic Theory of Agency: The Principal's Problem, American Economics Review, 63(2), 134-139.
Rozeff, M. S. (1982), Growth, beta, and agency costs as determinants of dividend payout ratios, Journal of Financial Research, 5, 249259.

Suwaldiman dan Ahmad, A. (2006). Pengaruh Insider Ownership dan Risiko Pasar terhadap Kebijakan Dividen, Sinergi, Kajian Bisnis dan Manajemen, 8(1), 53-64.

-. 2006. IDX Statistic 2006. Bursa Efek Indonesia. http://www.idx.co.id.

2007. IDX Statistic 2007, Bursa Efek Indonesia. http://www.idx.co.id 2008. IDX Statistic 2008, Bursa Efek Indonesia. http://www.idx.co.id.

2009. IDX Statistic 2009, Bursa Efek Indonesia. http://www.idx.co.id.

2010. IDX Statistic 2010, Bursa Efek Indonesia. http://www.idx.co.id.

--, Undang-Undang RI Nomor 36 Tahun 2008 Tentang Perubahan Keempat Atas Undang-Undang Nomor 7 Tahun 1983 Tentang Pajak Penghasilan.

-.----------, Undang-Undang RI Nomor 17 Tahun 2000 Tentang Perubahan Ketiga Atas Undang-Undang Nomor 7 Tahun 1983 Tentang Pajak Penghasilan.

-.-, Undang-Undang RI Nomor 28 Tahun 2007 Tentang Perubahan Ketiga Atas Undang-Undang Nomor 6 Tahun 1983 Tentang Ketentuan Umum Dan Tata Cara Perpajakan.

----------, Undang-Undang Republik Indonesia Nomor 40 Tahun 2007 Tentang Perseroaan Terbatas.

Undang-Undang RI No. 8 Tahun 1995 tentang Pasar Modal.

Peraturan Pemerintah Republik Indonesia Nomor 19 Tahun 2009 tentang Pajak Penghasilan atas Dividen Yang Diterima atau Diperoleh Wajib Pajak Orang Pribadi Dalam Negeri.

, Peraturan Menteri Keuangan No.111/ PMK.03/2010, tentang Tata Cara Pemotongan, Penyetoran, dan Pelaporan Pajak Penghasilan atas Dividen yang Diterima atau Diperoleh Wajib Pajak Orang Pribadi Dalam Negeri.

---, 2003. Jobs and Growth Tax Relief Reconciliation Act of 2003. http://www.gpo. gov/fdsys/pkg/PLAW-108pub127/html. Diakses tanggal 23 April 2010. 